Immuno-Ophthalmology 


\section{Developments in Ophthalmology}

Vol. 30 


\title{
Immuno-Ophthalmology
}

\author{
Volume Editors $\quad$ U. Pleyer, Berlin \\ M. Zierhut, Tübingen \\ W. Behrens-Baumann, Magdeburg
}

43 figures, 2 in color, and 18 tables, 1999

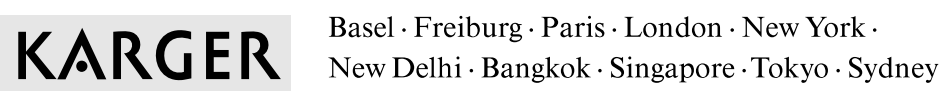




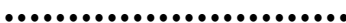

\section{Prof. Dr. U. Pleyer Prof. Dr. M. Zierhut Prof. Dr. W. Behrens-}

\section{Baumann}

$\begin{array}{lll}\text { Universităts-Augenklinik } & \text { Dept. of General } & \text { Universităts-Augenklinik } \\ \text { Charité Berlin } & \text { Ophthalmology } & \text { Otto von Guericke Universität } \\ \text { Augustenburger Platz 1 } & \text { University Eye Hospital } & \text { Medizinische Fakultät } \\ \text { D-13353 Berlin } & \text { Schleichstrasse 12 } & \text { Leipzigerstrasse 44 } \\ & \text { D-72076 Tübingen } & \text { D-39120 Magdeburg }\end{array}$

Continuation of 'Bibliotheca Ophthalmologica', 'Advances in Ophthalmology', and 'Modern Problems in Ophthalmology'

Founded 1926 as 'Abhandlungen aus der Augenheilkunde und ihren Grenzgebieten' by C. Behr, Hamburg and J. Meller, Wien

Former Editors: A. Brückner, Basel (1938-1959); H.J.M. Wewe, Utrecht (1938-1962);

H.M. Dekking, Groningen (1954-1966); E.B. Streiff, Lausanne (1954-1979);

J. François, Gand (1959-1979); J. van Doesschate, Utrecht (1967-1979);

M.J. Roper-Hall, Birmingham (1966-1980); H. Sautter, Hamburg (1966-1980);

W. Straub, Marburg a.d. Lahn (1981-1993)

ISSN $0250-375$

ISBN 3-8055-6863-0

Bibliographic Indices. This publication is listed in bibliographic services, including Current Contents ${ }^{\circledR}$ and Index Medicus

Drug Dosage. The authors and the publisher have exerted every effort to ensure that drug selection and dosage set forth in this text are in accord with current recommendations and practice at the time of publication. However, in view of ongoing research, changes in government regulations, and the constant flow of information relating to drug therapy and drug reactions, the reader is urged to check the package insert for each drug for any change in indications and dosage and for added warnings and precautions. This is particularly important when the recommended agent is a new and/or infrequently employed drug.

All rights reserved. No part of this publication may be translated into other languages, reproduced or utilized in any form or by any means electronic or mechanical, including photocopying, recording, microcopying, or by any information storage and retrieval system, without permission in writing from the publisher.

(C) Copyright 1999 by S. Karger AG, P.O. Box, CH-4009 Basel (Switzerland)

www.karger.com

Printed in Switzerland on acid-free paper by Reinhardt Druck, Basel

ISBN 3-8055-6863-0 


\section{Contents}

VII Preface

1 General Principles of Immuno-Ophthalmology Streilein, J.W. (Boston, Mass.)

24 Immunology of Graves' Ophthalmopathy Heufelder, A.E.; Spitzweg, C. (Munich)

39 Immunology of the Lacrimal Gland and Tear Film Sullivan, D.A. (Boston, Mass.)

54 Allergic Conjunctivitis Bonini, S.; Lambiase, A. (Rome); Juhas, T. (Kosice); Bonini, S. (Rome)

62 Clinical and Immunological Characteristics of Oculomucocutaneous Disorders Pleyer, U.; Niesen, U. (Berlin); Mondino, B. (Los Angeles, Calif.)

84 Scleritis Immunopathology and Therapy Sainz de la Maza, M. (Barcelona)

91 Ocular Hypertension and Glaucoma Associated with Scleritis and Uveitis

Aspects of Epidemiology, Pathogenesis and Therapy

Schlote, T.; Zierhut, M. (Tübingen)

110 Immunobiology of the Cornea

Pathophysiological Considerations and Clinical Implications

Pleyer, U. (Berlin) 
129 The Immunology of Corneal Transplantation Niederkorn, J.Y. (Dallas, Tex.)

141 Herpes Simplex Virus Type 1 Infection of the Cornea Heiligenhaus, A.; Bauer, D. (Essen)

167 Autoimmunity and Autoimmune Disease of the Eye Forrester, J.V. (Aberdeen)

187 Immune Regulation of Uveoretinal Inflammation Dick, A.D. (Aberdeen)

203 Ocular Infections in the Immunocompromised Host Bialasiewicz, A.A.; Knospe, V.; Richard, G. (Hamburg)

220 Immunotherapy of Uveal Melanoma

Ksander, B.R.; Chen, P.W. (Boston, Mass.)

231 Perspectives in Immunotherapy

Zierhut, M.; Schlote, T.; Stübiger, N.; Stiemer, R.; Kötter, I. (Tübingen)

245 Subject Index 


\section{Preface}

At the beginning of this century ophthalmology was one of the earliest medical disciplines to be influenced by the dynamic expansion of immunology. Many intellectually inclined ophthalmologists not only adapted the new theories but also contributed major 'insights' to immunology - facilitated by the eye as a model for immune-mediated processes. Organ-specific antigens were first identified in the human lens by Uhlenhuth in 1903, and as early as 1906 Elschnig identified uveal pigment as an autoimmune stimulus for intraocular inflammation. In the same year, the cornea was the first organ to be transplanted successfully in man. The particularly puzzling finding of keratoplasty survival without additional immunosuppressive therapy initiated extensive studies on the eye as an immunoprivileged site, an interest that still continues. At the end of this century, our concepts of immune-mediated diseases have evolved rapidly and basic observations have begun to put some of the major sight-threatening disorders into perspective.

The concept of this book is to provide the practicing and the resident ophthalmologist both with our present understanding of the pathogenesis of the most common immune-mediated disorders of the eye as well as give a practical approach to these diseases. This book is not a comprehensive review of practical treatment, but provides a thorough understanding of the pathophysiology and will therefore facilitate rational decision making. A number of well-reputed clinicians and laboratory scientists have contributed to this volume with their expertise and we are greatly indebted to them for their efforts. At the same time, we would like to acknowledge Dr. Thomas Karger and his team, in particular Susanna Ludwig and Priska Baumgartl, for providing support, even though this project took longer than originally anticipated.

We hope that this book will prove to be not only a useful text, but will also stimulate intellectual interest in 'immuno-ophthalmology'.

Uwe Pleyer, Berlin

Manfred Zierhut, Tübingen

Wolfgang Behrens-Baumann, Magdeburg 